\title{
Testicular thermography and seminal quality in bucks submitted to intermittent scrotal insulation in a tropical climate
}

\section{Termografia testicular e qualidade seminal em bodes submetidos à insulação testicular intermitente em clima tropical}

\author{
Maurício Francisco Vieira Neto ${ }^{1 *}$; Bruna Farias Brito"; Marcimar Silva Sousa"; \\ Maria Gorete Flores Salles ${ }^{2}$; Aderson Martins Viana Neto ${ }^{3}$; José Ferreira Nunes ${ }^{3}$; \\ Vicente José de Figueiredo Freitas ${ }^{3}$; Airton Alencar de Araujo ${ }^{3}$
}

Highlights

Intermittent testicular insulation compromised testicular thermoregulation in bucks.

Intermittent insulation causes seminal damage similar to testicular degeneration.

Thermograms were useful in the functional testicular evaluation after thermal stress.

Associating TIV with CASA allowed an accurate assessment of testicular degeneration.

\begin{abstract}
Testicular degeneration is highly prevalent in ruminants reared in a tropical climate like Brazil. Therefore, it is necessary to assess semen quality periodically in these animals. This study aimed to define standard images (thermograms) using infrared thermography (TIV), associated with a computerized seminal evaluation (CASA), to predict testicular alterations noninvasively. For this, 10 male goats were selected and their testes were insulated to evaluate the seminal quality and superficial testicular temperature recorded at four different phases: before, during, and after (early and later) insulation. Semen collection, rectal temperature (TR) and superficial testis (TS) by TIV were assessed for 60 days after insulation. Data are expressed as median and standard errors and were analyzed using analysis of variation with comparison between the periods using Tukey's test at $5 \%$ probability. Changes in seminal quality followed the same standard of changes in TS, with no influence of the latter on TR. The mean testicular temperature increased by more than $2^{\circ} \mathrm{C}$ above the normal mean testis temperature, with a significant increase $(p<0.05)$ in the before and

1 Students of the Doctoral Course of the Postgraduate Program in Veterinary Sciences, PPGCV, State University of Ceará, UECE, Fortaleza, CE, Brazil. E-mail: mauriciomacejo@hotmail.com; britobf@live.com; marcimarmv@hotmail. com

2 Prof. University of International Integration of Afro-Brazilian Lusophony, UNILAB, Redenção, CE, Brazil. E-mail: gorete@ unilab.edu.br

3 Profs., UECE, Fortaleza, CE, Brazil. E-mail: adersonv@gmail.com; ferreira.nunes@uece.br; vicente.freitas@uece.br; airton.alencar@uece.br

* Author for correspondence
\end{abstract}

Received: May 27, 2020 - Approved: Oct.19, 2020 
after insulation phases, and concomitantly reduced seminal parameters and almost returned to normal 60 days postinsulation. These changes in testis surface temperature associated with semen analysis allowed us to obtain pattern images of testicular degeneration, permitting prediction by TIV of testis alterations for later assessment of seminal quality.

Key words: Animal thermal confort. Testis thermoregulation. Buck semen evaluation.

\section{Resumo}

A degeneração testicular é altamente prevalente em ruminantes criados em clima tropical no Brasil. Portanto, é necessário avaliar a qualidade do sêmen periodicamente nesses animais. O objetivo deste trabalho foi definir imagens-padrão (termogramas) usando termografia por infravermelho (TIV), associada à avaliação seminal computadorizada (CASA) de maneira não invasiva, para diagnóstico de alterações testiculares. Para tanto, 10 machos caprinos foram selecionados e seus testículos insulados para avaliar a qualidade seminal e as temperaturas retal e testicular superficial, registradas em quatro momentos diferentes: antes, durante e cedo e tarde após a insulação. As coletas de sêmen e as temperaturas retal e testicular superficial pela TIV foram avaliadas por 60 dias após a insulação. Os dados foram expressos em média e erro padrão e submetido à análise de variância (ANOVA) com comparação entre os momentos pelo teste de Tukey a $5 \%$ de probabilidade. As mudanças na qualidade seminal seguiram o mesmo padrão das mudanças na temperatura da TS, sem influência do último na temperatura retal. A temperatura testicular média aumentou mais de 2 graus acima da temperatura média normal do testículo $(p<0,05)$ durante a insulação, em relação aos momentos antes e após a insulação, e concomitantemente redução nos parâmetros seminais com retorno a quase normalidade aos 60 dias após a insulação. Essas mudanças nas temperaturas da superfície do testículo associadas à análise do sêmen permitiram obter imagens padrões de degeneração testicular, possibilitando prever, por TIV, alterações testiculares para posterior avaliação da qualidade seminal.

Palavras-chave: Conforto térmico animal. Termorregulação testicular. Avaliação seminal caprina

\section{Introduction}

In northeastern Brazil, the reproduction of goats is influenced by the hard weather in the semi-arid climate of the hinterland or semihumid climate of the coast, with significant daily variations in temperature and relative humidity (Rocha et al., 2015; Salles, Souza, Rondina, Moura, \& Araujo, 2009). In these settings, male and female goats not accustomed to high thermal radiation may have low reproductive efficiency (I. C. S. Rodrigues, 2016; Souza et al., 2014).

In ruminants, the occurrence of thermal stress is one of the main factors involved in testicular degeneration, a multifactorial process that culminates in a reduction in seminal quantity and quality and increase in the number of sperm pathologies (Moreira, Moura, \& Araujo, 2001; Rocha et al., 2015). This condition may occur naturally or be induced by testicular insults (Alves et al., 2016) and may be reversible, depending on the cause of its genesis (Vieira et al., 2017). The irreversible sequelae, such as the occurrence of testicular fibrosis, may remain (Cavalcante et al., 2014a; Gabaldi \& Wolf, 2002).

Mild, moderate, and severe testicular degeneration have been frequently reported in animals reared in extensive and intensive 
systems in tropical climates, as in Brazil (Vieira, 2017). Controlled scrotal insulation has used for the study of testicular changes caused by experimental conditions. This makes it possible to simulate in a short period of time changes that occur in natural conditions, allowing the evaluation of testicular and seminal changes and their return to normality (Santos \& Simplicio, 2000; Moreira et al., 2001; Rocha et al., 2015).

Since reproduction depends on the quality of the ejaculation, periodic seminal evaluations must be performed in domestic ruminants to select and monitor male species (Vieira, 2017). Semen collection is usually performed using an artificial vagina or electroejaculation (Colégio Brasileiro de Reprodução Animal [CBRA], 2013), and the evaluation can be performed by direct optical microscopy (Vieira et al., 2017) or modern methods such as computerized analysis (Cavalcante, Brasil, Salgueiro, SalmitoVanderley, \& Nunes, 2014b).

Testicular activity monitoring can be done using noninvasive methods, such as Mode B Ultrasonography (Cavalcante et al., 2014a) and infrared thermography (Alves et al., 2016; Barca et al., 2020), which provides images that map areas of higher and lower temperatures on the body surface. This is useful for assessing the thermolysis and thermal adaptation capacity of the animal using thermogram maps (I. C. S. Rodrigues, 2016). Infrared thermography has already been used in other ruminant species, such as bulls (Romanello et al., 2018) and sheep (Alves et al., 2016; Kahwage et al., 2017).

Thus, this study aimed to evaluate testicular degeneration induced by intermittent scrotal insulation in goats, associating thermography with an evaluation of seminal quality by computerized analysis, in three phases: before, during, and after the process of insulation, which enabled better interpretation of thermographic maps in case of testicular degeneration that commonly occurs in animals reared in a tropical climate.

\section{Materials and Methods}

This study was approved by the ethics committee for the use of animals in research at the State University of Ceará, under protocol number 4565073/2018, and occurred from August to December 2018.

\section{Experiment execution location}

The experiment was carried out at the Integrated Nucleus of Biotechnology and Laboratory of Physiology and Reproduction Control of the Veterinary Faculty of the State University of Ceará, Itaperi campus, in the City of Fortaleza, located at $3^{\circ} 47^{\prime} 37^{\prime \prime} \mathrm{S}$ of latitude and $38^{\circ} 33^{\prime} 30^{\prime \prime} \mathrm{S}$ longitude south, with an altitude of $26.0 \mathrm{~m}$ above sea level. The local climate is type AW (tropical semi-humid), according to Köppen-Geiger, with an average ambient temperature varying between 26 and $28^{\circ} \mathrm{C}$ and an average annual precipitation of $1448 \mathrm{~mm}$. During the execution of the study, the average ambient temperature was $27.8^{\circ} \mathrm{C}$, and the relative air humidity was $71.1 \%$. Such data characterize an average temperature and humidity index of 78.16 , with a maximum value of 82 and a minimum of 76.5 (Thom, 1959). 
Selection and management of experimental animals

Ten 18-month-old crossbred goats with an average weight of $40 \mathrm{~kg}$ were selected. The health condition of the animals was verified through clinical and andrological examinations, associated with complementary laboratory tests (coproparasitological, blood analysis, and serum biochemistry). Each animal was kept in an individual $(3 \times 2 \mathrm{~m})$ covered area with access to a solarium; they received good quality water and specific commercial mineral salt for goats ad libitum. The feed consisted of Tifton 85 hay (Cynodon dactylon) and balanced, concentrated feed, meeting the nutritional requirements recommended by the National Research Council [NRC] (2007).

After 30 days of adaptation to the facility, feeding, and semen collection by electroejaculation, the animals were subjected to semen collection and measurement of the rectal temperature (TR) and superficial temperatures of the testicles. This seminal collection method was adopted because the sexual behavior of male goats is unpredictable after the process of testicular insulation (Viana, 2018). This ensured that during the entire experimental period, there was continuous semen collection, according to the CBRA procedure manual (2013).

\section{Experimental design}

Initially, data collection was performed once a week ( $T R$, seminal parameters, and testicular infrared thermography) for 3 consecutive weeks (D-17, D-10, and D-3) to verify and document the normal condition of the animals before insulation. Testicular insults (thermal bags) recommended by Rocha et al. (2015) and Alves et al. (2016) were placed over the animals' scrotums on day D0, initiating the insulation (during phase).

For 4 consecutive nights, the thermal bag was placed at 6:00 pm and removed at 6:00 am the following morning, following the protocol used in sheep by Viana (2018), adapted from Moreira et. al. (2001). This procedure is used to compromise testicular thermoregulation and simulate a condition of natural testicular thermal stress, which can alter the seminal quality already verified in rams (Moreira et al., 2001; Rocha et al., 2015) and goats (Santos \& Simplicio, 2000; Salles et al., 2009).

As shown in Figure 1, every day, during the period from D1 to D4, thermal bags were removed and the TR and testicular scrotal surface temperatures wereassessed. However, only at D4 was the semen collection resumed; as the method adopted (electroejaculation) is invasive (L. F. S. Rodrigues, 1997; Vieira, 2017), it was decided to minimize any additional stress and discomfort that interfered with the animals welfare during the intermittent testicular insulation process. The postinsulation period was divided into an initial period (early), started at D4 and a posterior period (later), from D39 until the end of the experiment (D60). 


\begin{tabular}{|c|c|c|c|c|c|c|c|c|}
\hline \multirow{4}{*}{ Before } & Days & Sunday & Monday & Tuesday & Wednesday & Thursday & \multirow[t]{13}{*}{ Friday } & \multirow[t]{13}{*}{ Saturday } \\
\hline & $\mathrm{D}(-17)$ & & & & & \multirow{3}{*}{$\begin{array}{c}\mathrm{C} \\
\mathrm{C} \\
\mathrm{D}(-3)=\mathrm{C}\end{array}$} & & \\
\hline & $\mathrm{D}(-10)$ & & & & & & & \\
\hline & $\mathrm{D}(-3)$ & & & & & & & \\
\hline \multirow[t]{2}{*}{ During } & D0-D4 & $\mathrm{D} 0=\mathrm{I}$ & $\mathrm{D} 1=\mathrm{T}+\mathrm{I}$ & $\mathrm{D} 2=\mathrm{T}+\mathrm{I}$ & $\mathrm{D} 3=\mathrm{T}+\mathrm{I}$ & $\mathrm{D} 4=\mathrm{C}$ & & \\
\hline & D1 1 & & & & & $\mathrm{C}$ & & \\
\hline \multirow[t]{4}{*}{ Early } & D28 & & & & & $\mathrm{C}$ & & \\
\hline & D25 & & & & & $\mathrm{C}$ & & \\
\hline & D32 & & & & & $\mathrm{C}$ & & \\
\hline & D39 & & & & & $\mathrm{C}$ & & \\
\hline \multirow[t]{3}{*}{ Later } & D46 & & & & & $\mathrm{C}$ & & \\
\hline & D53 & & & & & $\mathrm{C}$ & & \\
\hline & D60 & & & & & $\mathrm{C}$ & & \\
\hline
\end{tabular}

Figure 1. Schematic diagram of the experimental design.

C: collection of seminal data and thermography; T: testicular thermography; I: intermittent testicular insulation During.

TR and infrared thermography of the testicular region

On each semen collection day, the animals were properly restrained to measure the TR with a digital thermometer. The superficial temperature evaluation of the scrotal sac was performed using a method similar to that used by Alves et al. (2016) on each side of the scrotum, measuring the temperature at three different areas in the proximal, medial, and distal regions of the testicles.

Testicular thermograms were obtained using a thermographic camera that generated images of $640 \times 480$ pixels, located $1 \mathrm{~m}$ from the animal and with emissivity adjusted to 0.90 . The images were evaluated using the FLIR Quick Report program (FLIR Systems, USA), to obtain temperature data at the three areas of each testicle, as shown in Figure 2.

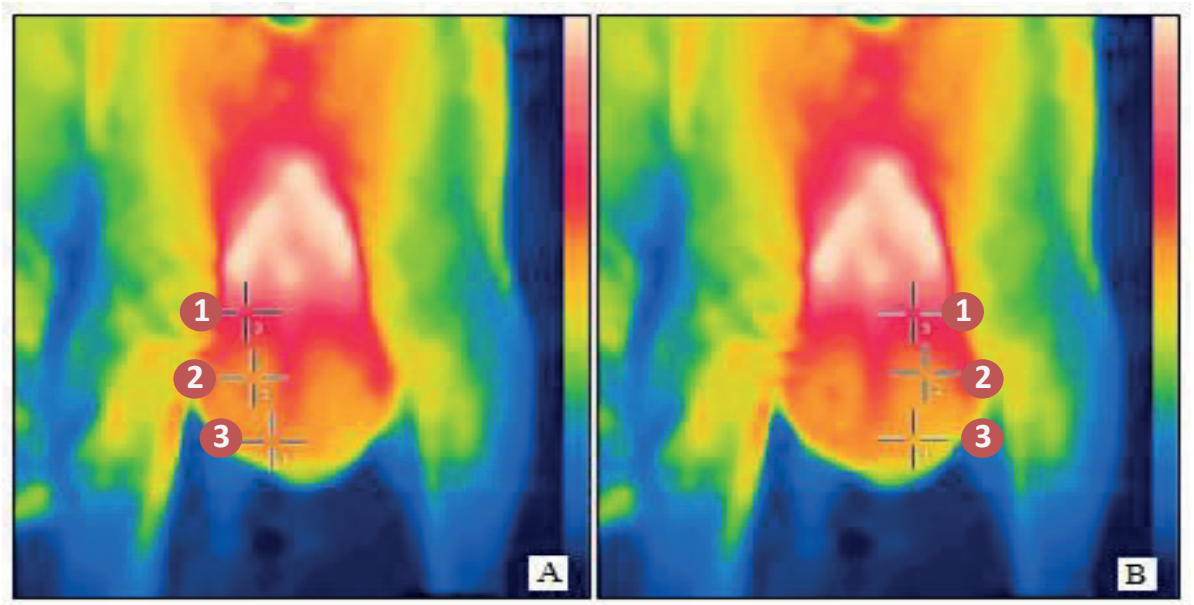

Figure 2. Testicular thermogram obtained during semen collection, showing the proximal (1), medial (2), and distal (3) areas of the posterior region of both testicles.

A: Left side; B: Right side. 1-Proximal area; 2-Medial area; 3-Distal area. 


\section{Collection and processing of seminal samples}

Semen was collected weekly at 8:00 a.m. using a $12 \mathrm{~V}$ automatic electroejaculator that emitted stimuli between 200 and 300 mA at intervals of 2-5 s (CBRA, 2013; Vieira et al., 2017). The collected ejaculate was immediately incubated in a water bath at $37^{\circ} \mathrm{C}$. Then, using a calibrated pipette, the total semen volume was measured and a 5 $\mu \mathrm{L}$ aliquot was separated to stain the slides with an equal amount of bromophenol blue, according to the methodology used by Medeiros et al. (2011), for counting the normal and abnormal cells.

Immediately after collection, sperm kinetics were assessed by computer analysis (CASA) using the Sperm Class Analyzer program (Microptic S. L, Barcelona, Spain), according to the methodology employed by Cavalcante et al. (2014b). Therefore, a $10 \mu \mathrm{L}$ sample of fresh semen from each ejaculate was diluted in $1 \mathrm{~mL}$ (1:100) of a solution containing coconut water powder (ACP), prepared in ultrapurified water, according to the manufacturer's recommendations (ACP Biotecnologia, Fortaleza, Brazil). Ten microliters of this dilution were placed in a Makler chamber (Sefi Medical Instruments Ltd., Haifa, Israel) and preheated to $37^{\circ} \mathrm{C}$ to evaluate the percentage of mobile and progressive sperms.

To assess sperm concentration, $10 \mu \mathrm{L}$ of fresh semen in $4.0 \mathrm{~mL}$ of formaldehyde saline (1:400) was used, measured with a micropipette, according to the recommendation by CBRA (2013). Cell counting was performed in a Neubauer chamber, following the recommendation by Chemineau, Cognie and Guerin (1991) for rams and bucks.

\section{Statistical analysis}

Statistical analyses were performed using SYSTAT software version 13 (USA). Data at different phases: before, during and after insulation were expressed as mean and standard error and submitted to the ShapiroWilk normality test. Those with abnormal distribution were transformed by $(\log (x+$ 1)) and those expressed as percentages transformed by the arccosine function (ACS). Then, data were evaluated using ANOVA with a $5 \%$ probability. When significant differences were found, the comparisons between the phases were performed using Tukey's test with multiple comparisons (two-by-two comparison probability matrix).

\section{Results and Discussion}

Infrared thermography (TIV) has been used as a method for assessing changes in testicular temperature in ruminant males, including rams (Alves et al., 2016; Kahwage et al., 2017), bulls (Kastelic, Coulter, \& Cook, 1995; Romanello et al., 2018; Barca et al., 2020), buffalos (Yadav et al., 2019), and bucks (Braz et al., 2019). However, most authors were restricted to the evaluation of the testicular surface temperature without considering a detailed evaluation of the thermal maps obtained from photographs. This study aimed to understand the clinical applicability of the thermograms obtained at different phases of this research, making it possible to monitor the testicular degeneration process, which is highly incident in reproducers reared in a tropical climate. This analysis of thermal maps obtained by TIV is similar to the evaluation of ultrasound or X-ray images, where the identification and diagnosis of probable alterations have, as a reference, the images of a healthy organ. 
The thermograms in Figure 3 represent a variation in the spectrum according to the intensity of the emission of infrared waves (heat emission) at three different areas of the testis (proximal, medial, and distal). Variations between white and red indicate higher temperatures, that is, greater heat emission. The yellow, green, blue, and lilac spectra gradually indicate the lowest temperatures, thus allowing a color gradient to be formed to interpret the thermograms (I. C. S. Rodrigues, 2016). There is a variation in the thermograms between the phases of the experiment and variation in the heat distribution on the testicular surface, according to the emission areas.

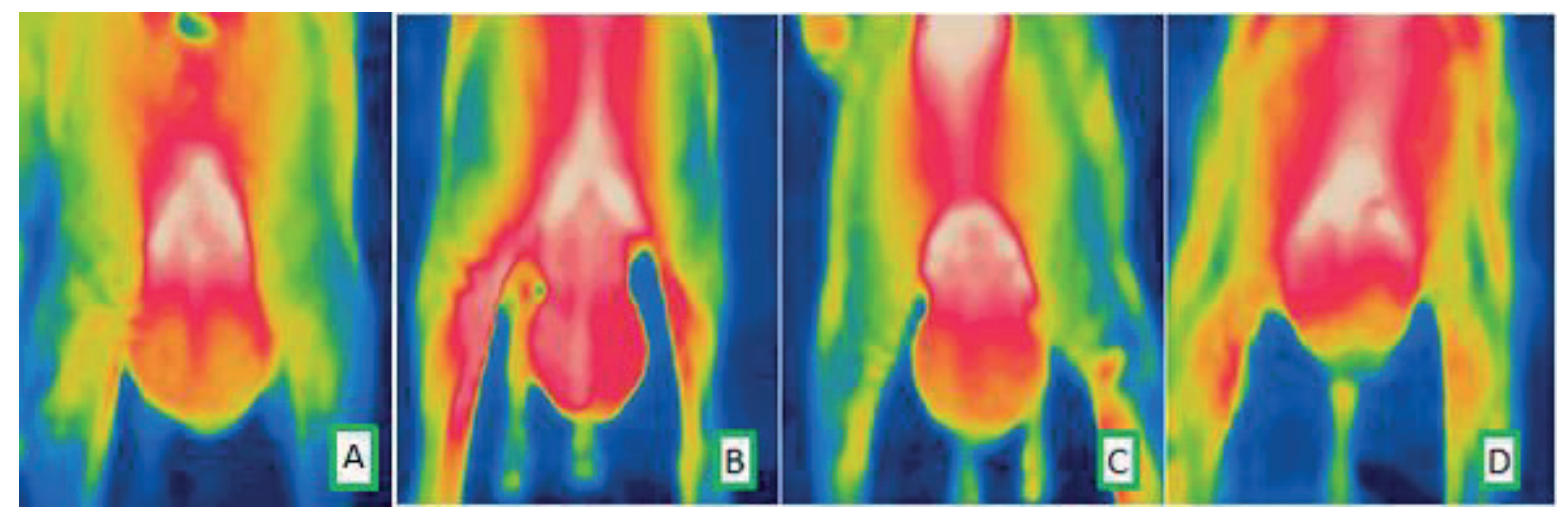

Figure 3. Thermographic images of the testicle posterior region in frontal view, obtained during the different phases of the experimental procedure.

A: thermographic representation of the before insulation phase; $B$ : last day of the during insulation phase on D4; C and D: after insulation phase, with C just after insulation on D11 (early) and D an image on D39 (later).

Figure $3 \mathrm{~A}$ represents the thermal image before insulation, in animals with healthy testicles, image 3B during the testicular insulation process, and $3 \mathrm{C}$ and $3 \mathrm{D}$ after insulation (C: early and D: later). In the $3 \mathrm{~A}$ image, there are three distinct thermal regions on the scrotal surface of the testicle not yet insulated, with the proximal red region representing a higher temperature $\left(33.12^{\circ} \mathrm{C}\right)$. The medial region is yellow, with an intermediate thermal band $\left(31.92^{\circ} \mathrm{C}\right)$ with a green halo in the most distal region of the testis (tail region of the epididymis), where the lowest temperature $\left(30.55^{\circ} \mathrm{C}\right)$ was measured.
This testicular temperature gradient is explained by the fact that the proximal region is close to the pampiniform plexus, where the arterial blood reaches temperatures close to that of the body $\left(38.13^{\circ} \mathrm{C}\right)(\mathrm{Hafez} \& \mathrm{Hafez}, 2004)$, as included in Table 1. In the medial region, the temperature is lower, since the arterial blood that reaches the testis has already been cooled by the venous return blood in the pampiniform plexus due to a countercurrent relationship between the testicular veins and arteries, lowering the temperature in this region. This represents most of the testicular mass, favoring spermatogenesis that requires a temperature of $2-6{ }^{\circ} \mathrm{C}$ below systemic temperature (Gabaldi $\&$ Wolf, 2002). 
Table 1

Temperatures obtained by thermography at different phases and areas of the testicles

\begin{tabular}{cccccccc} 
Phases & PRT & PLT & MRT & MLT & DRT & DLT \\
Before & $33.11+0.31^{\mathrm{A}}$ & $33.14+0.31^{\mathrm{A}}$ & $31.87+0.32^{\mathrm{Ab}}$ & $31.98+0.33^{\mathrm{Ab}}$ & $30.51+0.23^{\mathrm{AC}}$ & $30.58+0.27^{\mathrm{AC}}$ \\
\multirow{2}{*}{ During } & $34.48+0.23^{\mathrm{B}}$ & $34.67+0.22^{\mathrm{B}}$ & $34.42+0.22^{\mathrm{B}}$ & $34.56+0.24^{\mathrm{B}}$ & $33.68+0.23^{\mathrm{B}}$ & $33.82+0.24^{\mathrm{B}}$ \\
\multirow{2}{*}{ After } & Early & $33.23+0.19^{\mathrm{A}}$ & $33.19+0.17^{\mathrm{A}}$ & $31.76+0.20^{\mathrm{A}}$ & $31.60+0.21^{\mathrm{A}}$ & $30.35+0.23^{\mathrm{A}}$ & $30.52+0.18^{\mathrm{A}}$ \\
\cline { 2 - 7 } & Later & $32.94+0.13^{\mathrm{A}}$ & $32.88+0.14^{\mathrm{A}}$ & $32.00+0.17^{\mathrm{A}}$ & $32.07+0.17^{\mathrm{A}}$ & $30.87+0.20^{\mathrm{A}}$ & $30.81+0.17^{\mathrm{A}}$
\end{tabular}

PRT: proximal right testis; PLT: proximal left testes; MRT: medial right testis; MLT: medial left testis; DRT: distal right testis; DLT: distal left testes. Different uppercase letters in the columns and lowercase letters in the lines indicate a significant difference $(p<0.05)$.

In the distal region of the testis, where the tail of the epididymis is located, the lower temperature is because this region is less irrigated in relation to the others and has a greater number of sweat glands, which allows greater heat loss (Blazquez etal., 1994). In bucks with healthy testicles, Figure $3 \mathrm{~A}$ represents the standard for normal conditions, since in most animals this thermogram was visible at this phase, compatible with the findings of Viana (2018) in rams under the same conditions of intermittent testicular insulation. In Figure 3B, obtained on the last day of the insulation, there was a marked change in the thermal image of the testicles, mainly in the most proximal region of the scrotum, with a predominance of red and white in the background. This change in the thermogram is interpreted by the significant increase $(p<0.05)$ in testicular temperature in the proximal region $\left(34.58{ }^{\circ} \mathrm{C}\right)$, medial $(34.49$ $\left.{ }^{\circ} \mathrm{C}\right)$, and distal $\left(33.75^{\circ} \mathrm{C}\right)$, as shown in Table 1.

It can be seen in Figure $3 \mathrm{~B}$ that the testicles appear more bulky and in a lower and pendulous position than in Figure $3 \mathrm{~A}$, a consequence of the increase in testicular volume due to higher scrotal blood circulation with hyperemia, edema, and descent of the testicle due to relaxation of the cremáster muscle, bringing the testicles closer to the ground in an attempt to mitigate the thermal stress caused by thermal insult (Rocha et al., 2015; Viana, 2018). This shows that during the insulation process, there was severe impairment of testicular thermoregulation when compared to normality, as shown in Figure $3 \mathrm{~A}$.

Figure 3C shows the testicular thermogram immediately after the insulation; the red color is less intense in the presence of yellowish areas below the medial region, in which temperatures were below the during phase and similar to those of the early phase postinsulation (Figure 3A), thus revealing a cooling of the testicles, relieving the insult by intermittent insulation, as shown in Table 1 (proximal $34.58^{\circ} \mathrm{C}$, medial $31.68^{\circ} \mathrm{C}$, and distal $\left.30.44^{\circ} \mathrm{C}\right)$.

Figure 3D represents an image obtained in the later phase after insulation, and shows a different thermogram of $3 \mathrm{C}$, with three distinct color regions: proximal in white $\left(33^{\circ} \mathrm{C}\right)$, medial in red $\left(32{ }^{\circ} \mathrm{C}\right)$, and distal in yellow $\left(31.8^{\circ} \mathrm{C}\right)$, approaching the normal temperature shown in thermogram $3 \mathrm{~A}$, in which the testicles are healthy. 
Figure 4 represents the mean testicular (graph A) and TR (graph B). It was observed that the evolution of the average testicular temperature increased significantly $(p<0.05)$ at the time of insulation, with values above $34^{\circ} \mathrm{C}$, that is, on average $2^{\circ} \mathrm{C}$ above the temperature of the phases before and after the insulation, interfering with the normal functioning of the testis and epididymis, resulting in a decrease in sperm quality at the phase after insulation (Figure 5). TR was not influenced by the insulation process and remained constant within the normal range in all phases of the study. These results are similar to those found by Braz et al. (2019), who used buck-insulated testicles.
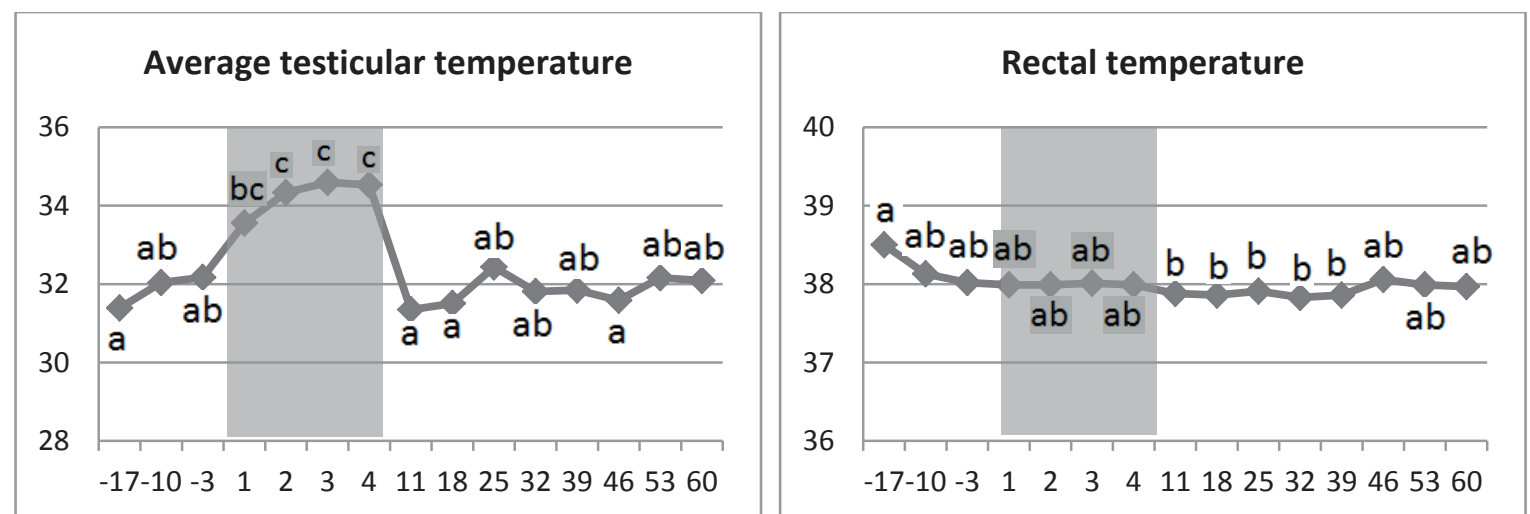

Figure 4. Graphs showing the evolution of average testicular temperature and rectal temperature over the days of the experiment.

Different lowercase letters indicate a statistically significant difference in the Tukey's test $(p<0.05)$.

According to Gabaldi and Wolf (2002), spermatogenesis occurs adequately at a temperature of $2 \square 6^{\circ} \mathrm{C}$ below body temperature, which remains constant within the normal range for goats, $38 \square 39.5$ (Salles et al., 2009). As there were no significant changes in TR during insulation, there was no influence of body temperature on the testicles or of the insulated testicle on the TR, corroborating the findings of Moreira et al. (2001), Rocha et al. (2015) and Viana (2018).

Analyzing the average testicular temperatures shown in Table 1, a significant increase $(p<0.05)$ was observed during the insulation (D1 to D4) in relation to the phases before and after insulation, regardless of the position of the testicle (right or left) or the evaluated areas (proximal, medial, and distal). In addition, within each phase, comparing the areas assessed between the right and left testicles, there was no significant difference between the contralateral testicular areas. However, the analysis between the areas evaluated within each phase revealed a significant difference between the areas in each testis, with a significant reduction in the temperatures of the medial and distal areas in relation to the proximal, except during insulation, when the temperatures were similar in the proximal and medial areas and significantly lower in the distal areas (approximately $1^{\circ} \mathrm{C}$ lower, $\mathrm{p}<0.05$ ). 


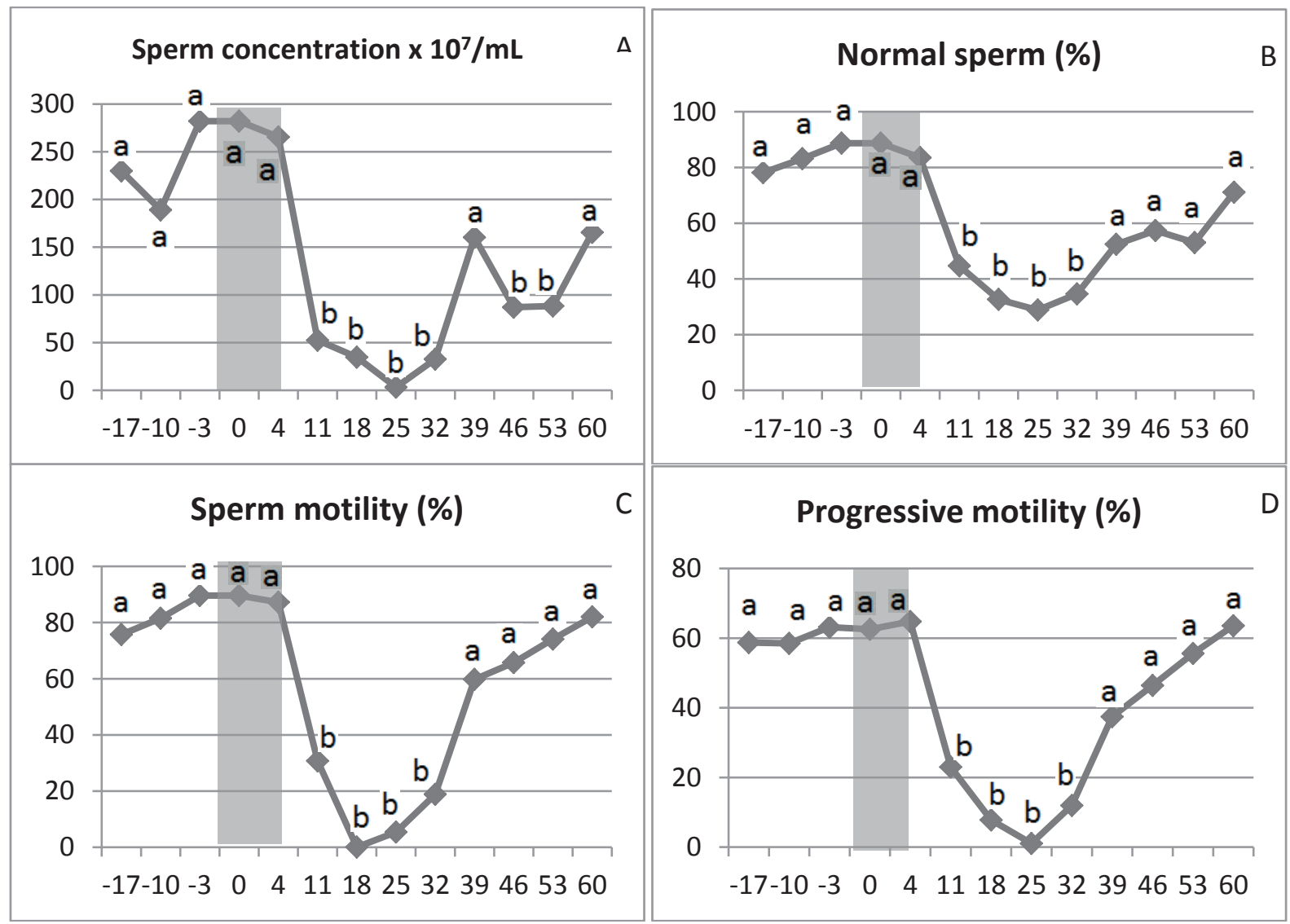

Figure 5. Seminal variables monitored during the 60 days of experimentation.

The gray stripe indicates the during insulation phase, when intermittent testicular insulation occurred. Different lowercase letters indicate a significant difference in the Tukey's test $(p<0.05)$.

Allseminal parametersshowedchanges throughout the experiment, with a significant decrease from D11 to D32, considered the earliest time of the postinsulation period, significantly increasing from D39 until the 60th day, except for sperm concentration, which decreased significantly ( $p<0.05$ ) between days 46 and 53 (later phase) and returned to normal on day 60 (Figure 5). Associating the thermograms with the seminal analyses at each phase, it was observed that before insulation (Figure $3 \mathrm{~A}$ ), the seminal parameters of sperm kinetics (percentage of mobile sperm and progressive motility), concentration, and percentage of normal sperm were within normal limits, following the recommendations of CBRA (2013). Day 4 (Figure 3B) represents the last day of insulation with removal of the insult, and the values, still within the normal range, can be explained by the maintenance of a viable sperm reserve in the tail of the epididymis, a result in accordance with those found by Moreira et al. (2001), Santos and Simplício (2000), and Rocha et al. (2015).

The early phase thermogram (3C) corresponds to days D11, D18, D25, and D32 and refers to the period in which there was a significant decrease $(p<0.05)$ in seminal 
characteristics in relation to the before insulation phase. These values of motility, concentration, and percentage of sperm represent a severe progressive degeneration, since at the 25th day after insulation, their values reached zero. In the thermogram presented at this phase (Figure $3 \mathrm{C}$ ), the testicles are predominantly red in color, indicating high heat emission and increased temperature in all regions of the organ (Table 1 ).

The reduction in the percentage of sperm motility (Figures $5 \mathrm{C}$ and 5D) can be explained by changes occurring in sperm cells during epididymal maturation (Hafez \& Hafez, 2004; Jones \& Dacheux, 2007; Vieira, 2017), since the thermal impact of the insulation during this period compromised sperm morphology by increasing the number of sperm defects (Moreira et al., 2001).

Figure 3D, equivalent to the later (postinsulation) phase (days 39 to 60 ), shows a quite different thermal image and is more heterogeneous than the previous (3C), approaching the thermogram (3A) just before insulation. The spermogram showed a rapid recovery of motility, sperm concentration, and a significant increase in the percentage of normal sperm cells, reaching values close to the phase before insulation with healthy testicles, but with mild signs of testicular degeneration that had not yet returned to normal concentration values and motility, as advocated by the CBRA (2013).

The early return of motility close to normal was probably due to the possibility that the thermal impact of the insulation was harmful only to sperm cells that were in the final stage of testicular spermatogenesis during the insulation phase (Moreira et al., 2001; Viana, 2018), besides the sperm selection performed by the epididymis, removing defective cells
(Jones \& Dacheux, 2007).

In general, the seminal parameters evaluated in the present study showed statistically significant differences in the second week after intermittent testicular insulation, showing a reduction in the quality of the ejaculates. However, most of them returned to normal condition after 4 weeks. This period was shorter than necessary to return to normal condition in bulls (Perumal, 2018) and rams subjected to full-time insulation (Moreira et al., 2001) or intermittent insulation (Viana, 2018) of the testes.

However, the values found are similar to those already obtained in goats (Oyeyemi, Adeniji, \& Olugbemi, 2011; Santos \& Simplicio, 2000), differing only in the early return to an almost normal condition justified by the intermittent insulation carried out here. This suggests that goats may have a greater tolerance to testicular thermal stress than sheep, considering that there may be an influence of the genotype even among breeds within the same species (Moura et al., 2019). However, additional studies need to be carried out on this subject, since the return to normality in bucks would require more observation time than used in this study.

In the present work, the analysis of thermograms (Figure 3 [A, B, C, and D]) at each phase shows different thermal images, allowing the identification of the condition of a healthy testicle (Figure $3 \mathrm{~A}$ ), in degeneration (Figure $3 \mathrm{~B})$, and finally, returning to an almost normal condition (Figures 3C and 3D). This shows a clinical analysis of abnormal physiological processes, since the thermogram allows a thermal description to identify sites with vascular changes. This technique becomes important because it does not require tactile manipulation, is not invasive, and does not 
cause unnecessary pain and suffering. Future studies on the use of thermography in the domain of veterinary andrology and adoption as a useful tool for farm veterinarians are warranted.

\section{Conclusion}

TIV, using thermogram analysis of intermittently insulated testicles associated with seminal analysis, allowed us to establish pattern images to differentiate the thermal normality from changes that may occur at various areas of the organ, thus constituting an auxiliary tool for the diagnosis of various degenerations that compromise seminal quality.

\section{References}

Alves, M. B. R., Andrade, A. F. C. de, Arruda, R. P. de, Batissaco, L., Florez-Rodriguez, S. A., Oliveira, B. M. M. de,... Vellone, V. S. (2016). Recovery of normal testicular temperature after scrotal heat stress in rams assessed by infrared thermography and its effects on seminal characteristics and testosterone blood serum concentration. Theriogenology, 86(3), 795-805. doi: 10.1016/j.theriogenology.2016.02.034

Barca, F. A. B., Jr., Koetz, C. K., Jr., Cruz Fávaro, P. da, Pereira, G. R., Menegassi, S. R. O., Morotti, F.,... Seneda, M. M. (2020). Infrared thermography and Doppler ultrasonography to evaluate the effects of scrotal insulation on testicular blood flow dynamics in bulls. Semina: Ciências Agrárias, 41(4), 1267-1278. doi: 10.5433/1679-0359.2020v41n4p1267
Braz, K. M. G., Ferreira, C. S., Ghirelli, C. O., Bosco, K. A., Flávio, N., Nascimento, D. C.,... Crespilho, A. M. (2019). Influência da bipartição escrotal sobre a capacidade de termorregulação e hemodinâmica testicular em caprinos. Veterinária e Zootecnia, 26, 1-10. Recuperado de https://rvz.emnuvens.com.br/ rvz/article/ view/169/103

Blazquez, N. B., Long, S. E., Mayhew, T. M., Perry, G. C., Prescott, N. J., \& Wathes, C. (1994). Rate of discharge and morphology of sweat glands in the perineal, lumbodorsal and scrotal skin of cattle. Research in Veterinary Science, 57(3), 277-284. doi: 10.1016/0034-5288(94)90118-X

Cavalcante, J. M. M., Brasil, O. O., Oliveira, R. V. de, Pessoa, A. W. P., Araújo, A. A. de, \& Nunes, J. F. (2014a). Ultrassonografia testicular em caprino com degeneração testicular associado a lesões escrotais: Relato de caso. Revista Brasileira de Higiene e Sanidade Animal, 8(1), 54-72. doi: 10.5935/1981-2965. 20140004

Cavalcante, J. M. M., Brasil, O. O., Salgueiro, C. C. D. M., Salmito-Vanderley, C. S. B., \& Nunes, J. F. (2014b). Criopreservação do sêmen ovino em meio diluente à base de água de coco em pó (ACP-102c). Ciência Animal Brasileira, 15(3), 344-353. doi: 10.1590/1809-6891v15i327834

Chemineau, P., Cognie, Y., \& Guerin, Y. (1991). Training manual on artificial insemination in sheep and goats. (Animal Production and Health Paper, 83). Rome: Food and Agriculture Organization of the United Nations.

Colégio Brasileiro de Reprodução Animal (2013). Manual para exame andrológico e avaliação de sêmen animal (3a ed.) Belo Horizonte, MG: CBRA. 
Gabaldi, S. H., \& Wolf, A. (2002). Importância da termorregulação testicular na qualidade do sêmen em touros. Ciências Agrárias, 2(2), 66-70. Recuperado de http://www. fea.br/Arquivos/Revistas\% 20 Cientificas/ Revista_Vol2_N2_2002/Vol2_N2_2002.pdf

Hafez, E. S. E., \& Hafez, B. (2004). Reprodução Animal. Barueri, SP: Manole.

Jones, R. C., \& Dacheux, J. L. (2007). Physiology of the epididymis. In F. R. Kandeel (Ed.), Male reproductive dysfunction: pathophysiology and treatment (pp. 7176). Nova York, NY: Informa Healthcare.

Kahwage, P. R., Esteves, S. N., Jacinto, M. A. C., Barioni, W.B., Jr., Pezzopane, J. R. M., Pantoja, M. H. A.,... Garcia, A. R. (2017). High systemic and testicular thermolytic efficiency during heat tolerance test reflects better semen quality in rams of tropical breeds. International Journal of Biometeorology, 61(10), 1819-1829. doi: 10.1007/s00484-017-1367-4

Kastelic, J. P., Coulter, G. H., \& Cook, R. B. (1995). Scrotal surface, subcutaneous, intratesticular and intraepididymal temperatures in bulls. Theriogenology, 44(1), 147-152. doi: 10.1016/0093-691X (95)001 55-2

Medeiros, A. A., Araujo, A. A., Moura, A. A. A., Cavalcante, J. M. M., Figueiredo, E. L., \& Rodrigues, L. F. S. (2011). Utilização do azul de bromofenol conservado a $4^{\circ} \mathrm{C}$ e $29^{\circ} \mathrm{C}$, como método de coloração vital para avaliação do espermatozoide ovino. Ciências Agrárias, 46(1), 287-297. Recuperado de http://ajaes. ufra.edu.br/ index.php/ajaes/article/view/273/171

Moreira, E. P., Moura, A. A. A. N., \& Araújo, A. A. (2001). Efeitos da insulação escrotal sobre a biometria testicular e parâmetros seminais em carneiros da raça Santa Inês criados no estado do Ceará. Revista Brasileira de Zootecnia, 30(6), 1704-1711. doi: 10.1590/S151635982001000700007

Moura, A. B. B., Brandão, F. Z., Esteves, S. N., Souza, G. N. de, Fonseca, J. F. da, Pantoja, M. H. A.,... Garcia, A. R. (2019). Differences in the thermal sensitivity and seminal quality of distinct ovine genotypes raised in tropical conditions. Theriogenology, 123, 123-131. doi: 10.1016/j.theriogenology. 2018.09.037

National Research Council (2007). Committee on the nutrient requirements of small ruminants, board on agriculture, natural resources, division on earth, \& life studies. Nutrient requirements of small ruminants: sheep, goats, cervids, and new world camelids. Washington, DC: National Academy Press.

Oyeyemi, M. O., Adeniji, D. A., \& Olugbemi, J. B. (2011). The spermiogram of mesterolone treated west African dwarf bucks with testicular degeneration. Nigerian Veterinary Journal, 32(1), 54-59. doi: 10. 4314/nvj.v32i1.68993

Perumal, P. (2018). Effect of scrotal insulation on semen quality profiles in mithun. International Journal of Bioresource and Stress Management, 9(6), 723-728. doi: 10.23910/ijbsm/2018.9.6.1926b

Rocha, D. R., Martins, J. A. M., Van Tilburg, M. F., Oliveira, R. V., Moreno, F. B., MonteiroMoreira, A. C..... Moura, A. A. (2015). Effect of increased testicular temperature on seminal plasma proteome of the ram. Theriogenology, 84(8), 1291-1305. doi: 10.1016/j.theriogenology.2015.07.008 
Rodrigues, I. C. S. (2016). Tolerância ao calor de ovinos lanados e deslanados criados em região semiárida do vale do São Francisco, Petrolina-Pe. Dissertação de mestrado, Universidade Estadual do Ceará, Fortaleza, CE: Brasil. Recuperado de http://www. uece.br/ppgcvwp/wp-content/uploads/ sites/6/2019/08/IntiRodrigues_Disserta \%C3\%A7\%C3\%A3o.pdf

Rodrigues, L. F. S. (1997). Efeito do método de colheita sobre os aspectos físicos, morfológicos e bioquímicos do sêmen de caprinos mestiços e ovinos deslanados da raça Santa Inês criados no estado do Ceará. Dissertação de Mestrado, Universidade Estadual do Ceará, Fortaleza, CE, Brasil.

Romanello, N., Lourenço, J. B. L., Jr., Barioni, W. B., Jr., Brandão, F. Z., Marcondes, C. R., Pezzopane, J. R. M.,... Garcia, A. R. (2018). Thermoregulatory responses and reproductive traits in composite beef bulls raised in a tropical climate Narian. International Journal of Biometeorology, 62(9), 1575-1586. doi: 10. 1007/s00484018-1557-8

Salles, M. G. F., Souza, C. E. A., Rondina, D., Moura, A. A. A., \& Araujo, A. A. (2009). Respostas fisiológicas ao estresse térmico de bodes Saanen em clima tropical. Ciência Animal, 19(1), 19-28. Recuperado de http://www. uece.br/cienciaanimal/

Santos,D.O.,\&Simplício,A.A.(2000).Parâmetros escroto-testiculares e de sêmen em caprinos adultos submetidos à insulação escrotal. Pesquisa Agropecuária Brasileira, 35(9), 1835-1841. Recuperado de https:// www.scielo.br/scielo.php?pid=S0100204X2000000900016\&script=sci_arttext
Souza, P. T., Salles, M. G. F., Costa, A. N. L., Carneiro, H. A.V., Souza, L. P., Rondina, D., \& Araujo, A. A. (2014). Physiological and production response of dairy goats bred in a tropical climate. International Journal of Biometeorology, 58(7), 1559-1567. doi: 10.1007/s00484-013-0760-x

Thom, E. C. (1959). The discomfort index. Weatherwise, 60, 12-57.

Viana, A. M., Neto. (2018). Parâmetros seminais e proteoma do plasma seminal de carneiros morada nova submetidos a insulação escrotal intermitente. Tese de doutorado, Universidade Federal do Ceará, Fortaleza, CE, Brasil. Recuperado de http://www.repositorio.ufc.br/bitstream/ riufc/31436/3/2018_tese_amvneto.pdf

Vieira, M. F., Neto. (2017). Efeito da Flunixina Meglumine na atividade espermática de machos ovinos e caprinos. Dissertação de mestrado, Universidade Estadual do Ceará,Fortaleza, CE, Brasil. Recuperado de http://www.uece.br/ppgcvwp/wp-content/ uploads/sites/6/2019/08/MauricioVieira Disserta\%C3\%A 7\%C3\%A3o.pdf

Vieira, M. F., Neto, Rodrigues, I. C. S., Silva Leles, J. da, Araújo, É. P. de, Viana, A. M. V., Neto, Carvalho, F. V.,... Araújo, A. A. (2017). Effect of Flunixin Meglumine administration on seminal characteristics of male sheep and goat. Semina: Ciências Agrárias, 38(5), 3145-3154. doi: 10.5433/16790359.2017 v38n5p3145

Yadav, S. K., Singh, P., Kumar, P., Singh, S. V., Singh, A., \& Kumar, S. (2019). Scrotal infrared thermography and testicular biometry: indicator of semen quality in Murrah buffalo bulls. Animal Reproduction Science, 209, 106145. doi: 10.1016/j. anireprosci.2019.106145 